Educational Research for Social Change (ERSC)

Volume: 7 Special Issue June 2018

pp. 46-59

ersc.nmmu.ac.za

ISSN: 2221-4070

\title{
Recognition as Reparation: A Participatory Approach to (Mis)recognition and Decolonisation in South African Higher Education
}

\author{
Talita Calitz \\ University of Pretoria \\ talita.calitz@up.ac.za \\ talitam/calitz@gmail.com
}

\section{Abstract}

In this paper, I present narratives drawn from a participatory research project in which students contributed to the everyday work of decolonising higher education. As part of the scholarly and activist impetus for decolonising South African universities, the narratives draw attention to patterns of misrecognition in undergraduate student experiences. The first part of the paper outlines an intersectional approach to student experiences, to illustrate how binaries underpin epistemologies, pedagogy, and relationships at the university. In the final section, I outline principles drawn from student narratives that can be used reframe student recognition as part of the broader process of decolonising South Africa higher education.

Keywords: decolonising, higher education, recognition, participatory research, South Africa

\section{Copyright: (c) 2018 Calitz}

This is an open access article distributed under the terms of the Creative Commons Attribution Non-Commercial License, which permits unrestricted non-commercial use, distribution, and reproduction in any medium, provided the original author and source are credited.

Please reference as: Calitz, T. (2018). Recognition as Reparation: A Participatory Approach to (Mis)recognition and Decolonisation in South African Higher Education. Educational Research for Social Change, 7(0), 46-59. http://dx.doi.org/10.17159/2221-4070/2018/v7i0a4

Talita Calitz iD http://orcid.org/0000-0001-7611-3317

\section{Introduction: \#Feesmustfall and the Decolonial Moment}

The decolonial turn in South African higher education is reenergising debates about untransformed structures, cultures, and relationships in higher education. New vocabularies are emerging around questions of knowledge, race, redistribution, and mutuality in a postapartheid context (Booysen, 2017; Heleta, 2016; Keet, Sattarzadeh, \& Munene, 2017; Kamanzi, 2017; Luckett \& Naicker 2016; Mama, 2016; Nkopo, 2015; Nwadeyi, 2017). Student and academics' call for decolonising higher education brings into focus the intersectional nature of structural injustice (Vally \& Motala, 2014). Decolonising the South African university presents an opportunity to take up the unfinished work of transformation 
and to drill deeply into the binaries created by the colonial, apartheid, and neoliberal influences on the public university. \#Feesmustfall has also refocused attention on colonial and apartheid-era ideologies and practices that are complicated by universities under pressure to respond to market demands and become globally competitive (Boni \& Walker, 2013; Naidoo, 2010). In response to the disruption of relational and epistemologic foundations of higher education, university communities have an opportunity to "think through these broader societal challenges and to provide students with access to alternative ways of envisioning the world and interpreting their experiences" (Hendricks \& Leibowitz, 2016, last para.). Yet, despite the fertility of this moment, investment and support across university structures have been uneven, with arguably disproportionate attention to incidents of violence and disruption. For instance, evidence that most students were not involved in the \#Feesmustfall protests has been used to dismiss student protests as a radical movement without substantial claims. This downplays the possibility that students who voted to continue their studies may not be unaffected by the issues raised during \#Feesmustfall, but that the risks and trade-offs diminish their freedom for participation in social movements.

The aim of this article is to contribute a microanalysis of how intersectional oppression impacts on student participation in higher education. I make the argument that an important part of decolonising South African public universities is redistributing not only material resources but also challenging the ontological binaries at the heart of structural oppression. Student narratives analysed in this paper suggest that structural patterns of status and value embedded in higher education continue to frame black, working-class students "as disadvantaged, as pathological, as unworthy of respect" (Fraser as quoted in Bozalek, 2012, p. 146; see also Fraser, 2013; Sayer, 2005). Despite such deficit framing, I argue that in addition to protest movements, students have been resisting institutional cultures and challenging these patterns of value in acts of resistance. Individual narratives show how students claimed space, time, and energy to challenge pathologising histories and to reframe their agency despite structural inequalities.

\section{Participatory Research ${ }^{1}$}

The student narratives analysed in this article are part of a broader qualitative research project that explored how opportunities for participation are distributed across the student body. The rationale for the research was to create a shared platform that students could use to relate to the challenges of being a black, first-generation student at a historically white, Afrikaans university, while gaining insight into the resources and agency that students used to negotiate and resist such challenges ${ }^{2}$. The qualitative data was collected during 2013 and 2014 using a combination of individual interviews and focus groups. I worked with eight undergraduate students across the social sciences to create individual digital narratives, or short multimedia films, about their experiences at university. The process of constructing student narratives was intentionally relational, and the formality of interviews was mitigated by the regular interaction during focus groups, social gatherings, or WhatsApp messages. Students shaped and constructed their narratives during an iterative process of individual interviews and digital narrative production sessions, focus groups, text messages, conversations, research workshops, informal interactions on campus, and social events. The research process for each

\footnotetext{
${ }^{1}$ Although students viewed the project as an opportunity to understand their own agency and that of their peers, there are important limitations to research conducted by a white researcher about the lived experiences of black students. I acknowledge that there will be many omissions, blind spots, and points of complicity, despite trying to engage as relationally as possible with student narratives.

${ }^{2}$ The position of black students at a historically white university is an important part of the research context, and is not intended to work as a simplistic binary. Research shows that working-class students across different racial groups may also have trouble cultivating belonging in higher education (Leathwood \& O'Connell, 2003).
} 
student was unique, with some engaging in multiple individual sessions, producing and discussing their digital narratives, while others chose to work independently.

The reason for using participatory methodology was to begin deconstructing the hierarchy of researcher-researched (Cammarota \& Fine, 2008; Kemmis, McTaggart, \& Nixon, 2013). For example, themes in student interviews were analysed by me and the research participants as part of the research project. Four months into the project, the scope was extended because of the students' request to expand the original four months data collection period. This extension enabled me and the research participants as a team to engage with individual narratives, themes, and findings, and to deepen our understanding of how university structures, cultures, and relationships limit equal access to academic opportunities, while downplaying student experiences of violence, discrimination, and othering. I also included student voices in response to accusations that calls for decolonisation are vague and under theorised, and fail to articulate explicit parameters of change (Pithouse, 2015). Instead, narratives show that students have been articulating what a decolonised university would look like, both during \#Feesmustfall and in the years leading up to the protests, and that vagueness or misunderstanding might be attributed to undervaluing student voices (see Nwadeyi, 2017). Finally, it was important to use student narratives as evidence that while protesting students used their agency to resist institutional constraints, other students behind the scenes are engaging in the everyday work of resisting the deficit gaze or assimilation into dominant cultures.

\section{A Conceptual Framework for (Mis)recognition}

The analysis of participant experiences draws on Nancy Fraser's status-based notion of recognition that is situated alongside claims for economic redistribution (Fraser, 2000). Fraser defined recognition as "the status of individual group members as full partners in social interaction" (2000, p. 113). This duality of status and redistribution makes her approach particularly responsive to an absence of material resources exacerbated by the misrecognition of working-class students' social, cultural, and emotional resources (Luckett \& Naicker 2016; Reay \& Ball, 2005; Walker, 2012). My analysis of misrecognition is complemented by Sayer's (2005) analysis of how socioeconomic class brings together the importance of material resources and recognition for socially excluded groups. Unequal patterns of material distribution diminish recognition for working-class students. Therefore, it is important to consider distribution and recognition as interrelated, given that "the everyday micro-politics of class are very much about recognition and misrecognition" (Sayer, 2005, p. 53). Working-class students in particular are vulnerable to the distributional inequalities, which limits their access to the resources needed to participate in higher education.

My analysis of student experiences is also framed by the work of activists and scholars who engage with decolonisation at the nexus of knowledge, research, and identity. The aim of this critical engagement between decolonial theory is to offer an analysis of (mis)recognition in South Africa higher education. Primary texts include Achille Mbembe's Critique of Black Reason (2017), Ngũgĩ wa Thiong'o's Decolonising the Mind (1994), and a public address on decolonising higher education by scholar-activist Lovelyn Nwadeyi (2017). I used these texts to analyse the knowledge structures, pedagogies, cultures, and relationships identified by the research participants in their experiences at university. The choice of texts and scholars reflects a diversity of thinkers who work within the decolonisation debate, and introduces new voices, while including both written and oral texts. While my approach to decolonisation is intersectional in the consideration of race and class, I position race as the primary binary that needs to be deconstructed. For this reason, I selected texts that position race as a foundational aspect of persistent inequality in postcolonial South Africa (see Alexander-Floyd, 2012 , on the danger of losing race in intersectional analyses). 
My conceptual framework starts with the assumption that the project of transformation has failed to recognise the humanity, presence, and agency of many black, working-class, and rural students (Fataar, 2017, April, Personal transcript of keynote presented at South African Education Research Association forum, North West University, South Africa). Misrecognition is often an embodied experience, and its existence is difficult to quantify, although there is evidence of structural racism at South African universities (Department of Education, 2008). While visible incidents are important evidence of racist violence, misrecognition can be found in the accumulation of everyday microaggressions, silences, differential treatment, avoidance, and selection that is difficult to quantify (Hendricks \& Leibowitz, 2016). For these reasons, it is necessary to dissect the structural roots of misrecognition, as a core function of the decolonising project, to avoid misrecognition being misappropriated as an empty signifier of student demands. To illustrate the complex intersection of race and class, I found Lelo Macheke's (2015) blog account of her experiences useful in framing the research. Macheke is a black middle-class student who published her experiences of the 2015 student protests at Rhodes University, and narrated this structural exclusion. As Macheke (2015) witnessed the public testimony of a black working-class student, Macheke at first assumed that she and her fellow student shared the othering, discrimination, and pathologising as black women at a predominately white institution:

"I am black. I am a woman. I was raised by my grandmother. I come from a working-class background." (para. 5)

"The culture here tells us that we need to qualify ourselves each and every day to maintain the fact that we deserve to be here," she affirms. She manages to quantify one of the most elusive and violent experiences endured by the black skin, in a single sentence. (para. 7)

"They hurl insults at us. They call us stupid. They call us angry for no reason. They call us illogical. Yet, they don't understand the lived experience of what it means to have the colour of THIS skin on this very campus. There is no cushion that burdens the blow of being black in this institution!" (para. 9)

Macheke then identified a rupture in the student's narrative, and realised that even though she and the speaker were both black women negotiating the oppressive racist cultures of the university, that her experiences as a middle-class student were profoundly different. While the working-class student was excluded by the white, middle-class, and elite culture of the university, Macheke risked being assimilated into its culture, as she explained (2015):

I am socially, economically, politically and even epistemologically of value to whiteness. White hegemony has recognised my capability to understand its culture; it has praised me for participating in it, but more so, it rewarded me generously for assimilating into it. (para. 12)

My inclusion into white hegemony translates into me being an exclusive member of an exclusive, yet dominant society. .. I have had to master the skill of negotiating my identity in ways which are emotionally violent and intellectually complex. (para. 14)

As Nwadeyi (2016) noted, consensus has not been reached on the structural, human, material, and psychological consequences of colonialism and the apartheid system that constrain commitment to, and resource investment in, decolonising projects. Therefore, the rationale for exhuming, examining, and dismantling structures and relationships of the postapartheid university is to enable a "complex understanding of the nature of what we are actually facing," instead of "the same old technobureaucratic fixes that have led us, in the first place, to the current cul-de-sac" (Mbembe, n.d., "The 
Philosophical Challenge," para. 2). I premise my analysis on the assumption that the misrecognition of black, working-class, and rural students who do not speak English as a mother tongue is an important reason why many aspects of curricula, pedagogy, institutional cultures, and relationships in South African higher education remained untransformed (see Calitz, 2017).

\section{Student Narratives of Misrecognition and Resistance}

In this section, I analyse student narratives in order to explore binaries that define knowledge structures, pedagogies, spaces, and relationships at the postapartheid university. It is important to understand how these binaries function in higher education if we hope to deconstruct their inherent power relations and emerge with new possibilities. One side of a binary is afforded a higher economic, cultural, and symbolic value. These binaries reflect political, social, and economic power imbalances, and filter down into knowledge systems, social structures, and human relationships. It is also important to understand how these binaries are not rigid, but shift over time, and contain within their parameters nuances that cannot be captured by a dualist interpretation of experiences. In higher education, important theoretical traditions that explicitly challenge these binaries include cultural studies, feminist theory, intersectionality, queer studies, critical race theory, and postcolonial theory (Hendricks \& Leibowitz, 2016). Structural inequalities that result from these binaries have been downplayed at a time when public universities face conflicting pressures to become competitive and market responsive, complicating their responsiveness to the public good. There is an increasing risk that the performativity discourse disguises inequalities in an identity-neutral language of individual success and failure, which makes it difficult to claim that a black student is treated unequally, that a working-class student does not have equal access, or that a rural student is marginalised. For these reasons, I argue that exhuming the evidence of binaries, and various forms of resistance to them, is an important aspect of the decolonising project.

\section{Negotiating Misrecognition and Race ${ }^{3}$}

In the past few decades, scholars and communities have begun to calculate the material and psychological costs of communities being positioned for centuries as less than fully human within the global community, and that the damage done to the individual and the community spans many generations (Keet et al., 2017; Mama, 2016; Mbembe, 2017). According to Mbembe, racialised oppression is

the daily work that consisted in inventing, telling, repeating, and creating variations on the formulas, texts, and rituals whose goal was to produce the Black Man as a racial subject and site of savage exteriority (2016, p. 28; see also Smith, 2012).

The marginalisation of black students' lives, bodies, values, and communities persists in South African higher education because the racial binaries have not been deconstructed. This emerges in \#Feesmustfall and experiences of staff and students and in the new forms of racial violence emerging, intensified by the contradictions of global economic tensions, which means that racism has a present and possible future (Mbembe, 2017). Based on an analysis of student narratives, in particular of the arrangements within pedagogy and between staff and students, the language of neoliberal meritocracy, achievement, and measurement reinforced existing racialised categories of dehumanisation, violence, and discrimination. These are used to communicate and repeat racialised

\footnotetext{
${ }^{3}$ I use black as a category that includes all South Africans who were been classified under apartheid as non-white or nonEuropean. Although I use the term in alignment with activism and scholarship that resists the pathologising of blackness, I realise that this approach has important limitations. In this article, black identity and culture is not meant to depict a homogenous identity or experience, but to capture the othering of diverse black African, coloured and Indian cultures, languages, religions, identities, and bodies that have not been classified as white during colonialism and apartheid.
} 
expressions of black, working-class, and rural identity without actual references to identity categories. In the quotation below, Kea, a black, working-class student describes her experience of a lecturer who misrecognised her academic potential:

The lecturer would write ... "Whose words are these?! Are those your words?!" It's like we're not capable of writing such [an essay]. If ever something sounds intelligent, or it sounds like it makes sense, it's not yours. Because if ever she reads your essay, and she looks at you, and how you speak in class, she's like, "That person can't write this essay." Because we wrote our essay at home instead of writing it in class, so that's why she didn't believe us. I almost got crushed emotionally.

In this experience, Kea's race intersected with her class and rural identity to create a complex intersection of vulnerability in the classroom and in her interaction with the lecturer. Decolonising a university would have to examine how these iterations of misrecognition work silently within classrooms, and begin to challenge a deficit approach for students who, unlike Kea, may internalise assumptions of deficit based on identity categories. For working-class students, recognition from lecturers and peers is part of the system of "hidden transcripts" (Sayer, 2005, p. 64) that complicate lecturer and student relationships. In response, wa Thiong'o's vision of decolonising is the "search for a liberating perspective within which to see ourselves clearly in relationship to ourselves and to other selves in the universe" (1994, p. 87; see also Mbembe, 2016).

Condorrera, a black, working-class student, describes her experience of misrecognition below:

Our lecturer said, "Well, you're going to write this test and I don't feel that one of you is going to pass. I don't see even one of you getting five percent for this test." So when we left this class, another [black] student said, "I didn't like the comment he made. It means he doesn't have confidence in us." So the lecturer should have actually told us what to do to nail the test. But in fact, he didn't. ... And the test that he was referring to, none of us failed.... It's just that the passing rate was not what he expected. But had he told us what he wanted, and how he prefers us to answer his questions, maybe we could have done better.

Decolonising pedagogical relationships could examine how the performativity narrative in higher education has provided new forms of classification with which to transmit beliefs about black students' academic potential, while silencing overt discrimination based on race and class, and rural and language identity. Unlike Kea and Condorrera, Clarice was tentative in including references to race in her experiences of discrimination in higher education:

I don't want to put a race card on it, but just the sense for us, like l explained in my journal, the matchbox living, for us as Coloured people. Just to kind of make my story that there is more to life, than pay cheque to pay cheque.

Clarice grapples with the discourse of post-racialism, which often emerges in accusations of using the past to explain current inequalities, as a way to silence conversations about apartheid. It is troubling that students whose lives and communities are directly affected by race apologise for references to inequality, especially in the context of a university where racial tension, violence, and discrimination have been and continue to be a reality. In the analysis, having to apologise for references to poverty and racial oppression reflects the dangers of rushing to a post-racial discourse, which negates the freedom that students have to speak freely about racial injustices and inequalities without the need to justify their stance or to fear being branded as radical, political, or resistant. Such hesitance to acknowledge race also points to the silencing of black students, in my experience often by white 
students, who used apartheid or race "fatigue" as reasons not to engage constructively with black students about race.

\section{Challenging Whiteness as a Construct}

Undoing racial binaries to open new possibilities for representation, identity, and mutuality requires that "the demythologizing of certain versions of history must go hand in hand with the demythologizing of whiteness" (Mbembe, n.d., "Demythologizing Whiteness," para. 9). According to Mbembe, whiteness acts as a form of entrapment, which I argue isolates itself in iterations of denial, silence, and material privilege. Instead of elevating the myth of whiteness, a decolonising university can resist this myth and construct alternatives. Nwadeyi reminds us that this myth has left people across races dehumanised, and that "we must dismantle this inhumanity that we are all products of by reclaiming our collective humanity" (Nwadeyi, 2017; see also Zinn, Proteus, \& Keet, 2009).

Although the urgency of demythologising whiteness is yet to reach consensus and commitment across South African universities, students in the research project showed how they have been doing the work of demythologising whiteness as participation of their trajectories of academic becoming. Kea's narrative engages at length with coming to terms with being black at a historically white, Afrikaans university, and how she navigates relationships and pedagogy:

I come from a black school; I never interacted with white people. . . . [My perception of white people was that] white people just wanna hang out with white people. White people are bad people. They have a lot of money, and they're just ignorant. . . They always perfect, they rich, they always have everything they need.

Kea recognises the limits of whiteness as a construction, and resists this by using her mother tongue and being confident about her accent. Kea makes herself vulnerable by challenging her preconceptions based on race, and describes instances where white peers show openness to constructing spaces of mutuality. Yet, while Kea appreciates her white colleagues' interaction, she also identifies the importance of reciprocity:

I told myself I don't want a white roommate. The problem was, unless that person is willing to learn my language, and I learn Afrikaans, if she's Afrikaans, if she wants to learn my language, I can teach her my language.

The silent or passive response to the decolonising project from some white students and staff members suggests that undoing the myth of white superiority is an important aspect of the task that lies ahead. As much as material resources need to be reallocated, the emotional labour of resisting, reconstructing, and reconciliation, which too often has been the sole burden of historically oppressed communities, must be shared more equally by white staff members and students.

\section{Intersections of Race and Class}

\#Feesmustfall is an intersectional movement that focuses attention on the experiences of workingclass students, for whom resource distribution is crucial for access. Chetty and Knaus (2016) suggested that racism and class discrimination have been diminished in the protest movement because some students have been able to access the system with financial aid, while excluding a majority of workingclass students from participation. Alongside resource distribution, another dimension of the class struggle is to identify and deconstruct elite and middle-class practices, values, cultures, and vocabularies in higher education, especially in the way that these misrecognise race and rural identity. Because whiteness has not been demythologised and deconstructed in knowledge systems, cultures, 
and institutions, universities have become fertile spaces where students are given the opportunity to adopt the values and practices of an uncritical and unquestioning white, middle-class, and individualistic ethic, which widens inequality and creates a new underclass of black, rural, and workingclass students. While some students with valued educational, financial, and cultural resources and capital have the freedom to adapt to the dominant culture, which at an institutional level acts as evidence of integration, many students remain excluded (Macheke, 2015; Nkopo, 2015; Nwadeyi, 2016). In the research project, student narratives confirmed that there is a daily negotiation of Eurocentric, English and Afrikaans, white, and middle-class cultures. Narratives show both assimilation and resistance, depending on access to resources, students' school background, and an individual's trajectory.

Techniques, a black working-class male student, who attended a public school in a rural area, resisted assimilation into a white, English, middle-class identity. His digital narrative included images and quotations that resist the ideas of mainstream assessment as indicators of intelligence, and expresses a deep suspicion of the inequality of the education system. Although he was relegated to the margins of the university community, Techniques was not passive and creates a community of fellow students who try to find ways to start small businesses while studying, and approach local government for funding opportunities. His video shows the university as an exclusive space that denies students academic access because of insufficient funding. While excluded from the mainstream business of the university, academic life, culture, and residence life, he and his peers created an alternative space for learning, surviving, making money, and creating community on the fringes of the institution.

In the second digital narrative, Jared, a black male student from a middle-class family, designed his video as an advertisement for the university, with images of Jared participating in a male-model pageant on campus, involved in social events and residence activities, and with groups of racially diverse peers on campus. Unlike Techniques, who does not include any visuals of the university space, Jared's video is a narrative of belonging, inclusion, integration, and equal participation. His experience of the university had been positive, welcoming, and enriching. In his interview, he explained how the aspiration for middle-class integration started with the aspiration to attend a private school. Throughout his primary and high school experiences, he struggled to gain access to private schools: I went to a private school ... it's not a white private school; it's a black private school,
shockingly.

Interviewer: Why shockingly?

Because... when you say from a private school, people would immediately think that was a very diverse school. But, it was black, all black. It was not really what I wanted. I wanted to go to St. Andrew's or Grey College in Bloemfontein and I applied there, and they said no.

The value associated with private education is closely associated with race, with the "all black" school a second choice to the historically white schools. Jared tried again to gain access to a well-resourced school, which he incorrectly assumed was a private school, but was denied access because he had not begun in the first year of high school:

[The school] said that that if it's an international student, they have to take you from Grade Eight. Sort of groom you to be a Saint's guy. So, if they were going to take me from Grade Ten, I wouldn't necessarily be the Saint's guy. 
The intersectional of differential value in race and class identity is evident in his aspiration for a school that can "groom" him and transfer the values needed for acceptance into the dominant culture at the best universities:

I have a lot of friends that went to St Andrew's, these nice private schools, St Andrew's, Grey College, and Knysna Boys High. And they sort of have like a thing. They have that aura ... and it lasts for a very long time because they teach them manners and a lot of things that people don't really notice... the way they articulate themselves, the way they speak when they speak to their parents, when they speak to their peers. And, that is exactly what I wanted. I wanted to be groomed in such a good way. And the other things, that when you apply to certain 'varsities like Rhodes or UCT [University of Cape Town], they actually take the Saint's guy or the Grey guy more into consideration because they align with that vision.

The aim of this comparison is to show how race and class binaries are reinforced within academic institutions and in relational exchanges that reinforce ideas about racial, class, and language superiority. The point of this analysis is not to devalue Jared and other middle-class students' freedom to adopt, if they so choose, a middle-class identity as a way to access important networks, opportunities, academic engagement, career development, and friendships in higher education. I am also careful not to understate the opportunities for interracial friendships, interactions, and collaboration that middle-class students have contributed to on university campuses. Instead, my critique, as mirrored by Macheke's (2015) experience of assimilation, is of unquestioned middle-class, white values that open up advantaged positions and opportunities for students who have access to them due to economic resources, family capital, schooling, and, in some cases, pure luck.

Jared's narrative reflects important inaccuracies that give us information about how perceptions about elite access work to exclude young people. Although exclusion from an elite institution such as UCT is not written into policy, research into working-class school leavers suggests that aspirations for entry into higher education, especially elite institutions, is shaped by socioeconomic factors and perceptions about who "belongs" in higher education (Reay \& Ball, 2005; see also Berg, 2016; Mullen, 2011; Stich, 2012). Yet despite these institutional constraints, Jared is not assimilated into the dominant culture, but contributes unique capital, resources, and aspirations that shape his opportunities. The broader question for decolonising higher education is understanding, deconstructing, and then resisting how unquestioned assumptions about Eurocentric cultures, attitudes, values, and identity in higher education hold differential value that continues to reinforce binaries of race, class, language, and geography. In the narratives above, and in examples from other students, the students who struggle for recognition, participation, and belonging have been those from public, township, and rural schools who speak African languages and have associated accents, from working-class backgrounds, without the mobility to move into the dominant class, who are framed as intellectually or culturally inferior.

\section{Towards a Decolonising Approach to Recognition ${ }^{4}$}

The final section of the article suggests actions to move towards a decolonising approach to recognition. The theory and narratives in this paper suggest that the decolonial moment is in essence an opportunity to "restore the humanity stolen from those who have historically been subjected to processes of abstraction and objectification" (Mbembe, 2017, p. 182), and to question how these processes are reproduced through education. The space of the public university holds powerful

\footnotetext{
${ }^{4}$ Mbembe, 2017.
} 
resources that could contribute to unfinished work of transformation. Student experiences are a reminder that decolonising actions demands deep engagement, as Nwadeyi (2017) suggested:

\begin{abstract}
I don't think the decolonial project is going to be successful if we come out of it with the same categories and the same boxes. The other side of the tension, of course, is that you can't just plaster over something, so before we get to the point where we've undone those hierarchies, we have to first elevate blackness to mean something; we first have to elevate womanhood to mean something, to be considered human.
\end{abstract}

The call for decoloniality is not an identity project, but rather as Mbembe suggested, "a project of reassembling amputated parts, repairing broken links, relaunching forms of reciprocity without which there can be no progress for humanity" (2017, p. 182).

A decolonising recognition requires knowledge systems in which indigenous knowledge from the African continent and the global South are central. Recentring knowledge means undoing the value hierarchies that have pushed African and indigenous epistemologies to the margins of the university. Rewriting histories of the African continent demands "a critique of the dominant Eurocentric academic model" and "epistemic coloniality,' that is, the endless production of theories that are based on European traditions" (Mbembe, n.d., "Decolonizing in the Future Tense," para. 2; see also Korteweg \& Russell, 2012). As I have argued in this paper, bringing students into the research process is one way to begin expanding academic knowledge beyond the epistemic coloniality based on unchallenged hierarchies about who is able to produce knowledge, whose knowledge counts, and whose knowledge is included in curricula and pedagogy. Mbembe summarised this project as one that aims to

\begin{abstract}
redistribute as equally as possible ... the capacity to make disciplined inquiries into those things we need to know, but do not know yet; the capacity to make systematic forays beyond our current knowledge horizons. (2016, p. 30)
\end{abstract}

An important aspect of such enquiry is ensuring that people to whom stories and histories belong have the resources and institutional space to negotiate and construct their own histories (see also McNair, 2017).

A decolonising recognition requires deconstructed binaries that could turn human and research conversations back to the history of oppression, within the context of neoliberal realities. Instead of dismissive responses that deny the opportunity for interracial dialogue, mutuality could create opportunities for the collective actions needed to forge new identities, vocabularies, and shared spaces (Keet et al., 2017; Zinn et al., 2009). The aim of mutuality is to create a version of access "that will allow black staff and students to say of the university: 'This is my home. I am not an outsider here. I do not have to beg or to apologize to be here. I belong here'" (Mbembe, n.d., "Architecture, Public Spaces and the Common," para. 9). In the higher education landscape, racialised discrimination against black students and staff suggests that the work of reparation, reconciliation, and redistribution must be recentred as an institutional priority. Nwadeyi reflected on everyday racism as an invisible violence that cannot be experienced by people who are not persistently discriminated against because of their race, as "a daily psychological violence that manifests in every part of our lives" (Nwadeyi, 2017). While there is evidence of widening access and success for a more representative cohort of higher education students, the decolonial moment demands a closer examination of implicit pedagogies, cultures, and structures that reinforce these long-standing beliefs about racialised prejudice inferiority, and how these intersect with class, ethnicity, and language. We also need to ask how to create the university as a space of the commons, where black students are brought out of margins off campus and on campus. A decolonised university is where undergraduate black students are no longer positioned as signifiers 
of failure, poverty, pathology, violence, exclusion, and pity. To this end, all students must have the same freedom to belong, to become, and to create, away from a deficit gaze of Eurocentric knowledge systems, institutional structures, and cultural communities.

Mutuality at the decolonising university will be about rearranging space so that it is not middle-class whiteness that accommodates black, working-class rural, identity, knowledge, and relationship. Instead, it will decolonise the structures of human relationships to open up new epistemologies and vocabularies. Mbembe suggested that this deep belonging requires black students and staff to develop a pedagogy of presence:

Black students and staff have to invent a set of creative practices that ultimately make it impossible for official structures to ignore them and not recognize them, to pretend that they are not there; to pretend that they do not see them; or to pretend that their voice does not count. (n.d., "Architecture, Public Spaces and the Common," para. 17)

Mbembe (n.d.) reminded us that decolonisation is always relational, a "bundle of innate rights, capabilities and claims made against others, taken back from others and to be protected against others" ("Difference and Repetition," para. 3). Decolonisation is impossible in silence; we need to begin by exhuming the deep binaries that continue to dehumanise, silence, and distort the position of the students in higher education.

\section{Conclusion}

This article has engaged with the expanding debate on decolonising the public university in South Africa. Student calls for decolonisation during \#Feesmustfall have created a conceptual and tangible space in higher education that begins to uncover layers of institutional oppression that intensify the alienation of black students and staff at many South Africa universities. Instead of rushing towards a marketised university, there are new possibilities for researching alternatives that emerge from the global South, and in particular from the African continent (Chetty \& Knaus, 2016; Mbembe, n.d.). Decolonising requires a collective investment to create institutions where every member belongs equally, with the freedom to create, contribute, and resist. Mbembe summarised this shared intention as follows:

how to belong fully in this world that is common to all of us, how to pass from the status of the excluded to status of the right-holder, how to participate in the construction and the distribution of the world (Mbembe, 2017, p. 176).

While the postapartheid university has enabled a minority of black students to access higher education, scholars like Macheke and Nwadeyi and students like Kea and Techniques are calling for opportunities for higher education to interrogate and open up alternatives to dominant narratives. If university communities hope to avoid the failures of the transformation project, this moment demands a human and resource investment in sustainable research projects, pedagogies, and relationships that, instead of "tinkering with the margins" as we have done in the past, will equip staff and students with the capabilities that they need to reshape the contours of the university. Given the freedom to reimagine, both staff and students will invent new vocabularies and identity expressions as old and dehumanising binaries are unearthed, deconstructed, and rebuilt (Mbembe, 2016). This will be, in Mbembe's words, "the beginnings of a reparation through recognition, the first hint of a constitution of a beyond" (2017, p. xv). 


\section{References}

Alexander-Floyd, N. G. (2012). Disappearing acts: Reclaiming intersectionality in the social sciences in a post-black feminist era. Feminist Formations, 24(1), 1-25. http://doi.org/10.1353/ff.2012.0003

Berg, G. A. (2016). Low-income students and the perpetuation of inequality: Higher education in America. New York, USA: Routledge.

Boni, A., \& Walker, M. (2013). Human development and capabilities: Re-imagining the university of the twenty-first century. Oxon, UK: Routledge.

Booysen, S. (2017). Fees must fall: Student revolt, decolonisation and governance in South Africa. Johannesburg, South Africa: Wits University Press.

Bozalek, V. (2012). Interview with Nancy Fraser. The Social Work Practitioner/Researcher, 24(1), 136151.

Calitz, T. M. L. (2017). Designing capability-informed pedagogy using participatory student research. In M. Walker \& M. Wilson-Strydom (Eds.), Socially just pedagogies, capabilities and quality in higher education: Global perspectives (pp. 153-175). New York, USA: Springer.

Cammarota, J., \& Fine, M. (2008). Revolutionizing education: Youth participatory action research in motion. London, UK: Routledge.

Chetty, R., \& Knaus, C. (2016, January 14). \#FeesMustFall: SA's universities are in the grip of a class struggle. Mail \& Guardian. Retrieved from https://mg.co.za/article/2016-01-14-why-sasuniversities-are-in-the-grip-of-a-class-struggle/

Department of Education (DoE). (2008). Report of the Ministerial Committee on transformation and social cohesion and the elimination of discrimination in public higher education institutions: Final report. Pretoria, South Africa: DoE. Retrieved from http://www.voced.edu.au/content/ngv:61442

Fraser, N. (2000). Rethinking recognition. New Left Review, 3, 107-120.

Fraser, N. (2013). Fortunes of feminism: From state-managed capitalism to neoliberal crisis. New York, USA: Verso.

Heleta, S. (2016). Decolonisation of higher education: Dismantling epistemic violence and Eurocentrism in South Africa. Transformation in Higher Education, 1(1). Retrieved from https://www.thejournal.org.za/index.php/thejournal/article/view/9/31

Hendriks, C., \& Leibowitz, B. (2016). Decolonising universities isn't an easy process-but it has to happen. The Conversation. Retrieved from http://www.polity.org.za/article/decolonisinguniversities-isnt-an-easy-process---but-it-has-to-happen-2016-05-24

Kamanzi, B. (2016, April 28). Decolonising the curriculum: The silent war for tomorrow. Daily Maverick. Retrieved from https://www.dailymaverick.co.za/opinionista/2016-04-28-decolonising-thecurriculum-the-silent-war-for-tomorrow/\#.WYAvcoiGPIU

Keet, A., Sattarzadeh, A., \& Munene, A. (2017). An awkward, uneasy (de)coloniality: Higher education and knowledge otherwise. Education as Change, 21(1), 1-12.

Kemmis, S., McTaggart, R., \& Nixon, R. (2013). The action research planner: Doing critical participatory action research. New York, USA: Springer.

Korteweg, L., \& Russell, C. (2012). Decolonizing+ Indigenizing= Moving environmental education towards reconciliation. Canadian Journal of Environmental Education 17, 5-14.

Leathwood, C., \& O'Connell, P. (2003). "It's a struggle": The construction of the 'new student' in higher education. Journal of Education Policy, 18(6), 597-615.

http://doi:10.1080/0268093032000145863 
Luckett, K., \& Naicker, V. (2016). Responding to misrecognition from a (post)/colonial university. Critical Studies in Education. http://doi:10.1080/17508487.2016.1234495

Macheke, L. (2015, May 1). To be young, privileged \& black: A word on the mimicry \& assimilation of white hegemony [Blog post]. The SubUrban Zulu. Retrieved from https://suburbanzulu.wordpress.com/2015/05/01/mimickingwhitehegemony/

Mama, A. (2016). Decolonizing knowledges 101: In the master's house [Video file filmed by W. Kasibe]. Retrieved from https://www.youtube.com/watch?v=pXoisspygxU

Mbembe, A. (n.d.). Decolonizing knowledge and the question of the archive [Blog post]. Retrieved from https://africaisacountry.atavist.com/decolonizing-knowledge-and-the-question-of-the-archive

Mbembe, A. (2016). Decolonizing the university: New directions. Arts and Humanities in Higher Education, 15(1), 29-45. http://doi:10.1177/1474022215618513

Mbembe, A. (2017). Critique of black reason (L. Dubois, Trans.). Durham, USA: Duke University Press.

McNair, I. (2017, July 7). Our stories, if told by us, help heal us. Mail \& Guardian. Retrieved from https://mg.co.za/article/2017-07-07-00-our-stories-if-told-by-us-help-heal-us/

Mullen, A. L., (2011). Degrees of inequality: Culture, class, and gender in American higher education. Baltimore, USA: Johns Hopkins University Press.

Naidoo, R. (2010). Global learning in a neoliberal age: Implications for development. In E. Unterhalter (Ed.), Global inequalities and higher education: Whose interests are you serving? London, UK: Palgrave Macmillan.

Ngũgĩ wa Thiong'o. (1994). Decolonising the mind (Studies in African literature). London, UK: Heinemann.

Nkopo, A. (2015, September 8). We still don't belong here. The Star.

Nwadeyi, L. (2016, January 27). Courage, compassion and complexity: Reflections on the new Matieland and South Africa [Video file]. Retrieved from https://www.youtube.com/watch?v=JqaZVH7cUJo

Nwadeyi, L. (2017, March 9). Decolonising the curriculum: Justice, humanisation and healing through education [Video file]. Nigerians in South Africa. Retrieved from http://www.nigeriansinsouthafrica.co.za/2017/04/25/decolonising-the-curriculum-justicehumanisation-and-healing-through-education-lovelyn-chidinma-nwadevi/

Pithouse, R. (2015, October 21). A moment of possibility for universities. Daily Maverick. Retrieved from http://www.dailymaverick.co.za/article/2015-10-21-op-ed-a-moment-of-possibility-foruniversities/\#.VidJIH4rK03

Reay, D., \& Ball, S. J. (2005). Degrees of choice: Class, race, gender and higher education. Stoke on Trent, UK: Trentham.

Sayer, A. (2005). The moral significance of class. Cambridge, UK: Cambridge University Press.

Smith, L. T. (2012). Decolonizing methodologies: Research and indigenous peoples (2nd edition). London, UK: Zed.

Stich, A. E. (2012). Access to inequality: Reconsidering class, knowledge, and capital in higher education. Lanham, UK: Lexington.

Vally, S., \& Motala, E. (2014). Education, economy \& society. Pretoria, South Africa: Unisa Press.

Walker, M. (2012). A capital or capabilities education narrative in a world of staggering inequalities? International Journal of Educational Development, 32(3), 384-393.

http://doi:10.1016/i.ijedudev.2011.09.003 
Zinn, D., Proteus, K., \& Keet, A. (2009). Mutual vulnerability: A key principle in a humanising pedagogy in post-conflict societies. Perspectives in Education, 27(2), 109-119. 